\title{
需要リスクを考慮したPFIによる 再インフラ整備に関する研究
}

\author{
信州大学 高瀬 達夫"1 \\ 信州大学 小山健 ${ }^{* 1}$ \\ 信州大学大学院森 一 基 ${ }^{* 2}$
}

By Tatsuo TAKASE, Ken KOYAMA, Kazuki MORI

平成 11 年にPFI 法が制定されて以降、各自治体において社会資本整備事業計画につ いてPFI 事業としての成立可能性の検討が盛んに行われるようになったことに伴いPFI に関する研究も増大してきた。その事業可能性の検討の際に不可欠なのが費用便益の 計測であるが、この費用便益の計測手法に関してはこれまで数多くの研究がなされて いる。しかしながら計測の際には需要リスクが厳然として存在し、PFI 事業の成否のカ ギを握っているといっても過言でない。このリスクを緩和するためにこれまで公共主 体が金銭的補助を行ってきた。しかしながら従来の補助方式では需要の大きな変化に 対応できないことは近年の実例を見ても明らかである。そこで本研究は新たな補助方 式を提案し、事例研究に㧤いてその効果を比較検討する。

【キーワード】 PFI, 需要リスク，環境税

\section{1.はじめに}

PFI 法の制定後、各自治体に扔いては国のPFI 事 業に関する実施方針の策定及び検討に必要な調査に 対する補助制度等の支援・促進策に呼応するよう、 新たな公共事業に関してPFI 事業としての適用可能 性について検討が進められている。こうした取り組 みの結果、現実に実施された事例もあちこちで見ら れるようになってきた。しかしながらこれらの事例 は比較的規模の小さな事業に対して適用されたもの が殆どであり、大規模な整備事業に対しての取り組 みはあまり行われていないのが現状である。こうし た背景にはPFI 事業では採算性が重要視されている が、事業規模が大きくなるほど費用と便益の予測に 不確定要素が増加するため、PFI 事業として実施し にくくなってしまうことが挙げられる。

*1 信州大学工学部社会開発工学科

TEL026-269-5307

*2 信州大学大学院工学系研究科
事業の経営の成否は最終的には当然のことなが ら収支が黒字になりかつ初期投資を回収できるか否 かにかかってくる。しかし支出の面では効率化を図 ることによりある程度迄の予測は可能であるが、問 題は収入の予測を如何に正確に行うかにかかってく る。しかしながら一般的な事業における収入が施設 利用者からの料金収入に大きく依存しているうえに、 この施設利用者数を予測することが最も難しいのが 現状である。従って需要予測の精度を向上させれば 最も良いのではあるが、振り返ってみるとこれまで 様々なケースで将来需要の予測がなされてきたが、 殆んど失敗に終わっている。そこで本研究では敢え て将来の総交通需要量の予測を行わず、需要の変化 に伴い事業収支がどのように変化するかに着目した。

一方、都市整備事業において PFI 手法の導入可能 性が高い事業として期待される大規模事例として挙 げられるのは、新交通システムの導入や公共交通機 関の再整備であろう。この場合公共主体による金銭 
的支援が不可欠であるが、これまでの第 3 セクター 等の事業における自治体の金銭的支援は一般財源の 中から毎年一定の補助金を供出する形態を採ってい る事が多い。しかし、この支援方法は社会的な環境 の変化すなわち景気の悪化による公共主体の歳入減 少や施設利用者の急激な減少による事業収入の減少 に対応できないうえに公共主体の財政圧迫にも繋が つてしまう。

こうしたことに鑑み本研究では公共主体が供出 する補助金を一般財源でなく新たな財源から捻出す ることを考えた。そこで着目したのが、近年取り沙 汰されている環境に大きな負荷を与えている渋滞時 の自動車排出ガスである。この社会的損失をもたら すラッシュ時に都市中心部に流入する自動車に対し て環境税をかけることによって得られる資金を補助 金とすることを考えた。この手法は結果として公共 交通機関への転換を促すことにも繋がるという利点 も併せ持つ。本研究は具体的な既存の軌道・鉄道か ら LRT への再インフラ整備という具体的事例を採 りあげて需要減少というリスクが生ずる場合につい ての事業採算性の検討を行うものである。

\section{2. 既存研究と本研究の位置付け}

PFI 事業に関する調查・検討が活発になされるよ うになったことに伴いPFIに関する研究も様々な観 点から数多くなされるようになってきており、特に 経済・金融分野において顕著に見受けられるり。一 方、都市・交通計画の分野に転じてみると、上田ら 2),3)は便益帰着構成表を用いて PFI 事業の成立可能 性を判断するためのモデルを構築している。また織 田澤ら 4) はPFI 事業推進・成功のために不可欠な公 共主体からの支援策として公的債務保証を行うため のモデルを提案し、最適な保証水準について論じて いる。

また社会資本整備事業に伴うリスクに関する研 倇も数多くなされているが、各種リスクの巾でも特 に需要の不確実性に着目し、需要变動下における事

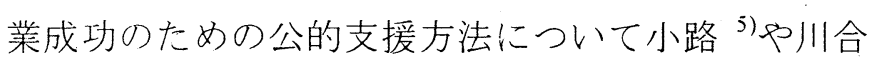
$ら^{6)}$ は提案している。そこでは需要数比例方式やバ ンド方式といった支援方法について論じられている。 一方、具体的な事業を取りあげて PFI 導入の可能
性について検討を行った研究としては梶井ら ${ }^{7}$ や藤 田ら ${ }^{8)}$ が挙げられる。前者は道の駅整備事業、後者 はモノレールの整備事業といった共に新規の整備事 業に対して計量化を行い、PFI 事業としての成立可 能性について検討されている。こうした事例研究は あまりされていないが今後増えていくことが予想さ れる。

本研究は将来地方都市において増えていくであ ろうと予想される軌道・鉄道から LRT の移行とい う再インフラ整備事業を例にとり、費用便益計測モ デルとして事業者・利用者間の均衡分析モデルを提 案し、PFI 事業としての可能性の検討を行う。また 併せて公的支援策として従来の一般財源からの供出 ではない新たな支援方法を提案し、需要リスクが生 じた場合について従来の支援策との違いについて検 討を行う。

\section{3. 計測モデル}

事業経営を効率的に進めていくにはもちろん利 用者を推定することは重要であり、またそれをもと に料金設定や運行頻度の設定といったサービスレベ ルを効果的に利用者に対して提供していく必要があ る。しかしながらこうしたサービスレベルの変化は 利用者の他の代替手段へまたは代替手段からの転換 という事柄に影響を及ぼし、シェアの予測間違いと いうリスクを生じさせることに繋がってしまう。こ のリスクを解消するために本研究では供給者と利用 者間の需給均衡モデルを提案する。

\section{（1）供給分析モデル}

本研究では事業者は利潤最大化行動をとるものと して捉え、以下のような供給関数を設定した。

$$
\begin{aligned}
\operatorname{Max}_{L} & =\sum_{i} \sum_{k}\left(Y_{i k L} \cdot C_{i k L}\right) \\
& -\left\{\left(Q_{L} \cdot R C_{L}+M R C_{L}\right) \cdot H+N \cdot M N C_{L}\right\} \\
& +\sum_{i} \sum_{k} x_{i k} \cdot Y_{C i k} \cdot E D
\end{aligned}
$$

(但し、 $i \neq k$ )

$P_{L}:$ LRT 事業者の純利潤

$Y_{i k L}:$ ゾーン $i, k$ 間の L R T 利用者数

$C_{i k L}:$ ゾーン $i, k$ 間の L R T 利用料金 


\section{$Q_{l}$ : : L R T の運行本数}

$R C_{L}: 1$ 車両 $1 \mathrm{~km}$ あたりの運行コスト

$M R C_{I}$ ： 1 営業キロあたりの管理運営コスト

$H$ ：L R T の営業距離 $(\mathrm{km})$

$N$ : 必要車両数

$M N C_{L}: 1$ 車両あたりの維持管理コスト

$x_{i k}:$ ゾーン $i, k$ 間で橋を渡るとき 1 ,

渡らないとき 0

$Y_{(i k}$ : ゾーン $i, k$ 間の自動車利用者

$E D$ ：環境税

但し右辺の第 3 項目は環境税を導入した場合に 限る。

ここで LRT 利用者数が総定員数を上回らないた めの制約条件として

$\operatorname{Max} Z_{a b} \leq Q_{L} S L$

$Z_{a b}$ : 駅 $a, b$ 間の利用者

$S L$ ：L R T 1 車両の定員数

また本研究ではＬＲＴは非常に公共性が強いた め、その公共的性質から冕脱しないために L R T 料 金は再インフラ整備前の料金を上回らないこととし， 以下の制約を加えることにした。

$B C_{i k R} \geq C_{i k L}$

$B C_{i k R}$ : ゾーン $i, k$ 間の整備前の料金

この利潤最大化に基づく供給モデルで決定される変 数は， $Q_{L}$ 及び $C_{i k L}$ である。

\section{(2) 需要分析モデル}

利用者は事業者が設定した料金と頻度等を考慮 して手段選択を行うものとしてモデル化を行うので あるが、近年このような需要分析モデルでは一般的 に非集計モデルが用いられることが殆どである。し かしながら本研究のように対象地域内における全 ODを対象にして非集計モデルを用いて計量化を行 う場合、同一 OD 間を利用するすべての人について 同じ個人属性を与えて分析することが多い。この場 合本来势ら!゙自動車運転免許を有しているかいない かによって選択可能な代替交通手段が異なってくる 筈はずが、OD が同じならば両者とも同じ手段に関 して同じ効用を持ってしまうことになってしまう。
また本モデルの目的は比較的手に入れやすいデータ (例えば PT 調査等)を使用し、実務レベルでも利用可 能な簡便な方法で計量化を行うことにある。従って、 本研究では LRT の利用率をゾーンの規模やサービ スレベルを説明変数として回帰させた式(2)に示す 型の集計モデルを用いることとした。

$$
\begin{gathered}
Y_{n i k}=A_{i k} \times y_{n i k} / \sum_{n} y_{n i k} \\
y_{n i k}=a_{n 0}+\sum_{m} a_{n m} \times \mathrm{X}_{n i k m}
\end{gathered}
$$

$n$ : 交通手段（ $L: \mathrm{L} \mathrm{R} \mathrm{T}, B$ :バス, $C$ : 自動車 $)$ $A_{i k}: ソ ゙ ー ン i, k$ 間の全交通の利用人数の総和 $y_{n i k}: ソ ゙ ー ン i, k$ 間の手段 $n$ の利用人数

$a_{n m}$ : 手段 $n$ における $m$ 番目のパラメ一タ

$\mathrm{X}_{n i k m}:$ ゾーン $i, k$ 間の手段 $n$ の $m$ 番目の説明变数 この需要分析モデルで決定される変数は， $y_{n i k}$ であ 万.

\section{(3) 需給均衡分析を用いた事業者利潤の計測}

先にも述べたように効率の良い経営を行ってい くためには最適なサービスの供給が不可欠である。 本研究では前述の供給・需要両者の分析モデルを 図-1の流れに沿って均衡分析を行い、事業者の利潤 を最大にするサービスレベルを求め、その状況下に おける利潤を測定する。ただし公共的性質を損なわ ないために運賃に関しては現在の運賃を上限とし、 また利用者の過度の詰め込みを防ぐために運行本数 は利用者数最大の区間での利用者数を一車両の定員 で割った值を用いることとした。

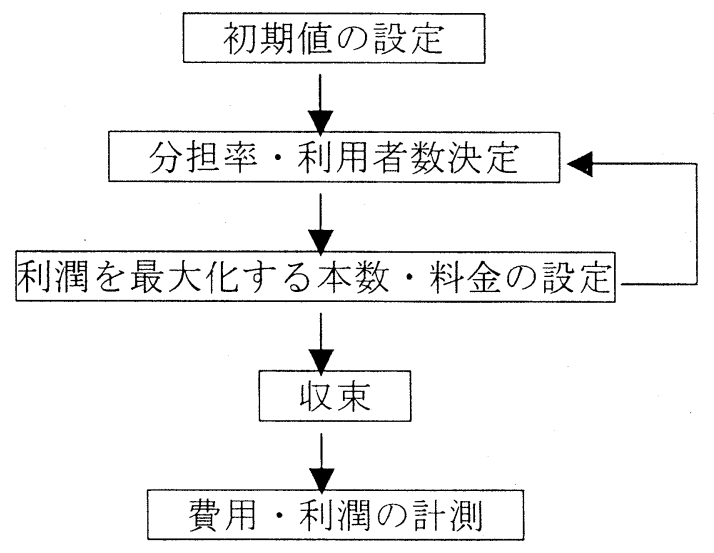

図-1 均衡分析の流れ 


\section{4. 事例研究}

本研究では富山市を例に挙げ、まず現在の交通手段 ごとの利用者分担モデルを作成する。そして次に既 存の軌道・鉄道から LRT への移行という再インフラ 整備を行った場合を例にとり試算を行い、その整備 事業のPFI 事業としての成立可能性の検討を行った。 具体的な LRT 導入方法は図-2 に示すような現在の 富山地方鉄道の市内軌道線と上滝線を改良して再イ ンフラ整備を行う事業計画と仮定した。

需要分析モデルを作成するにあたり本研究で用い た交通手段ごとの OD は「富山高岡広域都市圈 PT 調查」を基にして作成されたデータを使用し、そこ で用いられているゾーン内指標も併せて用いること とした。またゾーン間の移動にかかる費用や時間等 の説明変数については時刻表や道路地図等を用いた。

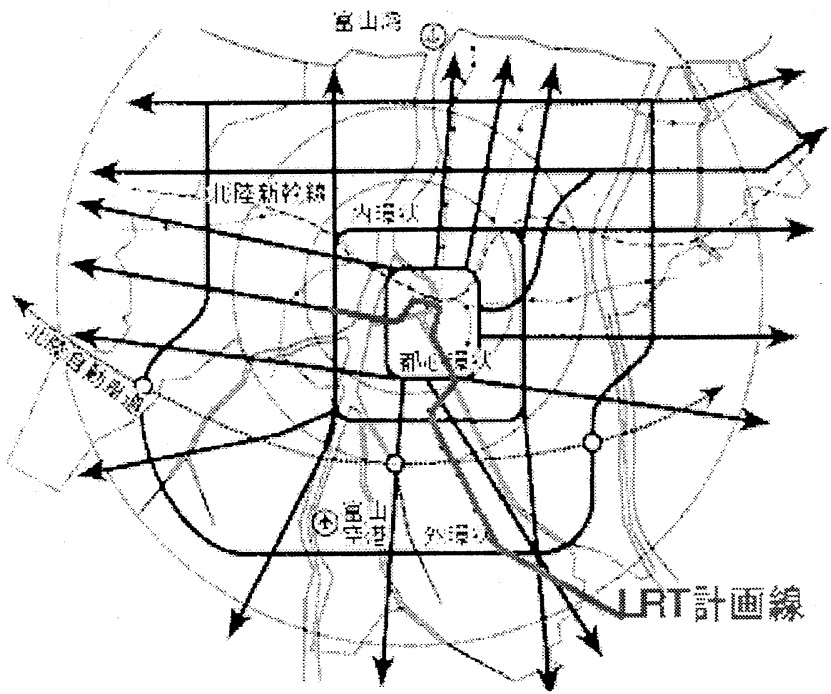

図-2 LRT 導入計画

表-1 鉄道利用モデル推定結果

\begin{tabular}{|l|rr|rr|}
\hline & \multicolumn{2}{|c|}{ ピーク時 } & \multicolumn{2}{|c|}{ オフピーク時 } \\
\hline 定数項 & 43.3 & $(1.4)$ & -73.6 & $(-1.4)$ \\
\hline 出発地人口 & -0.0049 & $(-3.1)$ & 0.0073 & $(2.4)$ \\
\hline 目的地人口 & 0.0009 & $(1.8)$ & 0.0035 & $(4.0)$ \\
\hline 高歯者人口 & 0.0361 & $(4.4)$ & -0.0242 & $(-1.6)$ \\
\hline 料金 & -0.0287 & $(-0.7)$ & -0.0355 & $(-0.5)$ \\
\hline 運行本数 & -2.03 & $(-1.0)$ & 0.705 & $(1.5)$ \\
\hline 所要時間 & -0.526 & $(-1.4)$ & -0.345 & $(-0.5)$ \\
\hline $\begin{array}{l}\text { 都市中心部 } \\
\text { 発着ダミ一 }\end{array} \mid 12.6$ & $(0.5)$ & 185.0 & $(4.1)$ \\
\hline 重相関係数 & \multicolumn{2}{|c|}{0.69} & \multicolumn{2}{|c|}{0.71} \\
\hline データ数 & \multicolumn{2}{|c|}{107} & \multicolumn{2}{|c|}{124} \\
\hline
\end{tabular}

但し：()内は t 值を示す。
表-2 バス利用モデル推定結果

\begin{tabular}{|c|c|c|c|c|}
\hline & \multicolumn{2}{|c|}{ ピーク時 } & \multicolumn{2}{|c|}{ オフピーク時 } \\
\hline 定数項 & 19.5 & $(0.9)$ & -11.3 & $(-0.2)$ \\
\hline 出発地人口 & -0.0018 & $(-1.5)$ & 0.0042 & $(1.8)$ \\
\hline 目的地人口 & 0.0009 & $(3.2)$ & 0.0023 & $(2.9)$ \\
\hline 高齢者人口 & 0.0142 & $(2.6)$ & -0.0107 & $(-0.9)$ \\
\hline 料金 & -0.0496 & $(-1.2)$ & -0.0385 & $(-0.5)$ \\
\hline 軍行本数 & & & 0.995 & $(1.3)$ \\
\hline 乗換ダミー & -45.8 & $(-2.6)$ & -54.8 & $(-1.4)$ \\
\hline $\begin{array}{l}\text { 都市中心部 } \\
\text { 発着ダミ一 }\end{array}$ & & & 84.0 & $(2.0)$ \\
\hline $\begin{array}{l}\text { 都市中心部 } \\
\text { 経由ダミ一 }\end{array}$ & 25.5 & $(1.9)$ & 13.5 & $(0.6)$ \\
\hline 所要時間 & 1.18 & $(2.4)$ & & \\
\hline $\begin{array}{l}\text { ゾーン間 } \\
\text { 距離 }\end{array}$ & -3.63 & $(-1.9)$ & & \\
\hline 重相関係数 & 0.67 & & 0.7 & \\
\hline データ数 & 59 & & 94 & \\
\hline
\end{tabular}

但し：()内は $\mathrm{t}$ 值を示す。

表-3 自動車利用モデル推定結果

\begin{tabular}{|c|c|c|}
\hline & ピーク時 & オフピーク時 \\
\hline 定数項 & $1425.6 \quad(1.5)$ & 4916.6 \\
\hline 出発地人口 & $0.0078 \quad(5.0)$ & $0.0409 \quad(9.7)$ \\
\hline 目的地人口 & $0.0150 \quad(10.8)$ & $0.0405 \quad(9.6)$ \\
\hline 成人人口 & $0.0033 \quad(1.5)$ & \\
\hline 費用 & $-0.920 \quad(-1.5)$ & $-3.03 \quad(-1.6)$ \\
\hline 駅ダミー & $-149.4 \quad(-2.6)$ & $-432.7 \quad(-2.5)$ \\
\hline 橋ダミー & $-50.1 \quad(-1.3)$ & $-203.1 \quad(-1.6)$ \\
\hline $\begin{array}{l}\text { 距離ダミ一 } \\
(5 \sim 10 \mathrm{~km})\end{array}$ & & $-231.8 \quad(-1.2)$ \\
\hline $\begin{array}{l}\text { 距離ダミ一 } \\
\text { (10km 以上) }\end{array}$ & $-52.3 \quad(-0.9)$ & $-431.7 \quad(-1.6)$ \\
\hline $\begin{array}{l}\text { 都市中心部 } \\
\text { 出発ダミ一 }\end{array}$ & $407.9 \quad(4.5)$ & \\
\hline $\begin{array}{l}\text { 都市中心部 } \\
\text { 目的ダミ一 }\end{array}$ & $\begin{array}{ll}-292.0 & (-3.4)\end{array}$ & \\
\hline $\begin{array}{l}\text { 都市中心部 } \\
\text { 発着ダミ一 }\end{array}$ & & $786.5 \quad(3.6)$ \\
\hline 重相関係数 & 0.71 & 0.73 \\
\hline データ数 & 296 & 343 \\
\hline
\end{tabular}

但し：()内は $\mathrm{t}$ 值を示す。

\section{(1) 需要分析モデルの推定}

今回は特にピーク時とオフピーク時では鉄道や バスの運行頻度が大きく異なることや、ピーク時に 
おける都心部への自動車流入量を明らかにするため にピーク時 (午前 7〜9 時) とオフピーク時別々にモ デルを作成した。またモデルの説明変数については 様々な試行の結果、表 $1 \sim 3$ に示した説明変数を用い ることとした。

説明変数として用いた駅ダミーとは出発地のゾ ーン内における利用可能な駅の有無を表し、橋ダミ 一とは OD 間を自動車で移動する場合の橋を渡る必 要性の有無を表している。そして両者は共に有る場 合：1、無い場合：0とする。また高齢者人口と成人 人口はともに出発地における人口を用いているが、

ここで考慮しなければいけないのは出発地人口との 相関についてである。しかしながら 3 つの変数相互 の相関係数は低い值が得られたため、重共線性につ いて悥慮する必要はないと思われる。

各モデルの推定結果を見てみると、 $\mathrm{t}$-值は殆どの モデルで出発地と目的地の人口で高くなっている。

このことは OD 間交通量が各 OD のゾーンの規模に 大きく影響を受けていると思われる。また個別に特 徵的なものとしては鉄道とバスのピーク時のモデル にお梳高齢者人口の $\mathrm{t}$-值が高くかつ正の值である ことや自動車利用モデルではピーク・オフピーク共 に駅ダミ一の $\mathrm{t}$-值が高くかつ負の值となっているこ とが挙げられる。これらのことからピーク時におい ては利用者層や利用目的が他の時間帯とは異なるこ とやン゙ーン内に駅がない場合自動車を利用する人が 多くなることが考えられる。

次に表 1〜3 に示されたパラメータ推定結果を用 いて(2)式に代入することにより各 OD・交通手段毎 の分担率および利用者数が求まる。本モデルの有効 性を倹討するために、3 交通手段間のシェアの実績

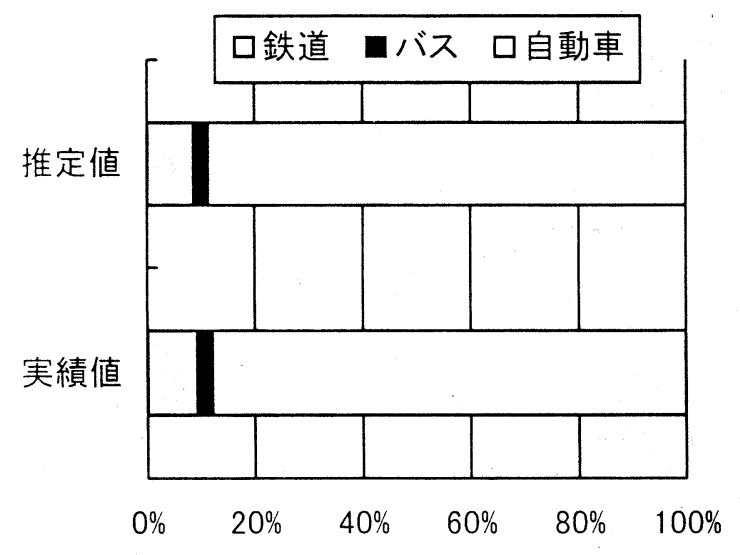

図-3 ピーク時の交通手段のシェア

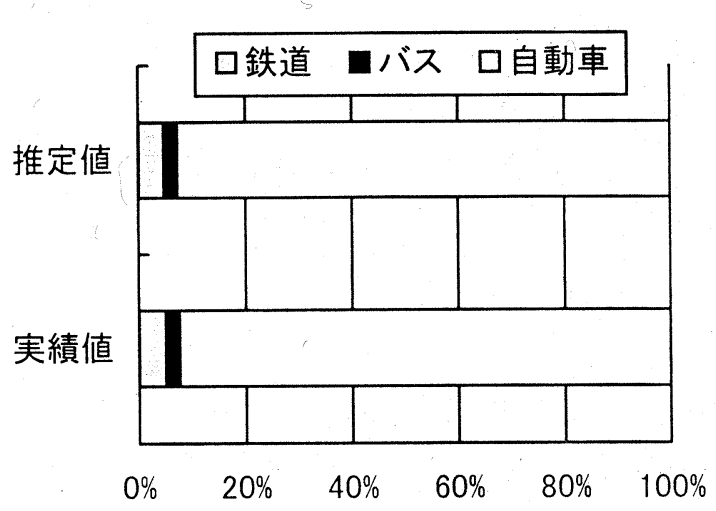

図-4 オフピーク時の交通手段のシェア

值とモデル推定の結果よりえられたシェアを比較し たものを図-3,4に示した。これによるとバスのシェ アは両者共にほぼ同じ結果が得られたが、鉄道にお いてはピーク時で総鉄道利用者の $6 \%$ 、オフピーク 時では $5 \%$ 程度過小評価する結果となった。

\section{（2）LRT 導入事業における JV 型 PFI 事業としての 成立可能性}

この均衡分析モデルを用いて図 2 に示したLRT 導 入計画事業における供給者の利潤の計測を行い、PFI 事業としての成立可能性を検討した。ここでは総需 要は一定であると仮定する。また LRT は既存鉄道の ように距離に応じた運賃形態とすることは難しいた め、定額料金として従来の最低料金である200 円と した。ただし南富山駅を通過する区間では、これま で別路線であることから 300 円と仮定した。また速 度の向上により平均 2 分の短縮、また乗換の必要が なくなった区間は 5 分短縮として計算した。

また(1)式中にある運行・管理運営・維持管理コス トについては平成 11 年度鉄道統計年報より、富山鉄 道(軌道)の営業費用を上記三つのコストに振り分け て各単位あたりの費用を算出し用いることとした。 なお税金については営業規模に比例すると考え、管 理運営コストに含むこととした。

表 4 に計測結果を示したが、初期費用には車両購 入費用や路線改修にかかる費用等を含んでいる。ま た年間の収入から費用を差し引いた利潤を算出した のち社会的割引率 $4 \%$ で 20 年間の総利潤の計測も 併せて行った。今回得られた結果では需要が将来に わたって一定ならば初期投資を回収でき、事業の採 算は合うと考えられる。結果としてこの仮定のもと 
では公的支援を得る必要はなく、単独の PFI 事業と しても行うことが可能である。

\section{表-4 利潤推定結果}

\begin{tabular}{|c|c|c||c|}
\hline & 年間利潤 & 20 年間利潤 & 初期費用 \\
\hline 金額 & 5.15 億 & 75.0 億 & 71.8 億 \\
\hline
\end{tabular}

\section{5. 需要リスクが生じた場合の公的支援策の違いに よる事業成立可能性の検討}

4 章では公共主体からの金銭的支援を受けなくて も経営可能という結果が得られたが、あくまでも将 来需要が一定という状況下でのことである。事業開 始後は例え需要が減少した場合でも初期費用が減額 されることは無く、ただ遊休車両が増えてしまうだ けであることは自明である。こうしたリスクが厳然 として存在する以上、公共主体が何らかの公的支援 策を予提示しない限り、民間事業者が事業経営に 参入することは難しい。また金銭的支援策について も従来からの定額補助方式では需要の大きな変化に 対応できないことは第三セクター方式の失敗例を見 れば明らかであろう。

こうした支援策について最近の研究では需要数 比例方式等の新たな方式が提案されてきている。し かしながら現実には一般財源からの支出は予め予算 の中に組み込む必要があるため、一年遅れの対応に ならざるを得ない。そこで本研究では都市中心部に 流出入及び通過する自動車に課税し、その財源を公 的補助金として充当するものとする。本研究での具 体的な課金方法は富山市中心部の神通川に架かる橋

（富山北大橋から有沢橋までの 4 つの橋）をピーク 時に通過する車両に対して環境税（渋滞時における 自動車排気ガスが引き起こす社会的損失に対する対 価を排出者に負担してもらうという目的税）を徽収 することとした。

本章では公的支援策の違いが需要リスク（ここで は特に総需要・鉄道利用者の減少に的を絞って論ず るものとする）に伴ってどのように変化するか計測 を行った。

\section{(1) 総需要が減少する場合}

まず総需要が将来減少した場合についての検討 を行った。表-5における5つのケースそれぞれにつ いて 20 年間の累積費用と累積利潤を求めた。鉄道に
おける耐久年数等を考慮すると 20 年間での初期投 資の回収が一つの目安であろう。累積費用曲線と累 積利潤曲線が交点を持てば事業化可能であるといえ る。ただし両曲線の違いをより明確にするため、図 5〜10 中の 50 億円以下の部分をここでは省略した。

図 5〜9 中の環境税は、橋を通行する自動車 1 台 ごとに 100 円ずつ徵収し、そのうち半分を徵収にか

表 -5 総需要減少 5 つのケース

\begin{tabular}{|l|l|}
\hline & \multicolumn{1}{|c|}{ 総需要減少の方法 } \\
\hline 1 & 20 年間変化なし \\
\hline 2 & 20 年で $5 \%$ 減少 \\
\hline 3 & 20 年で $10 \%$ 減少 \\
\hline 4 & 10 年で $5 \%$ 減少、その後一定 \\
\hline 5 & 10 年で $10 \%$ 減少、その後一定 \\
\hline
\end{tabular}

\begin{tabular}{|ll}
\hline - - - 累積費用 & $-\longrightarrow$ 累積利潤(支援なし) \\
\hdashline- - - - 累積利潤(環境税導入) $\longrightarrow$ 累積利潤(定額支援)
\end{tabular}

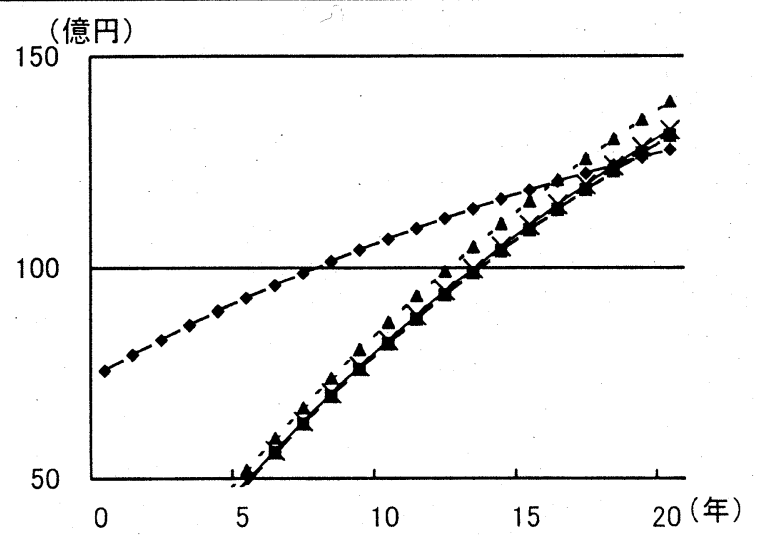

図-5 累積費用と利潤（ケース 1）

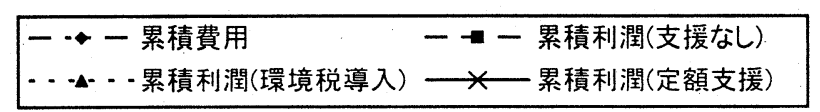

(億円)

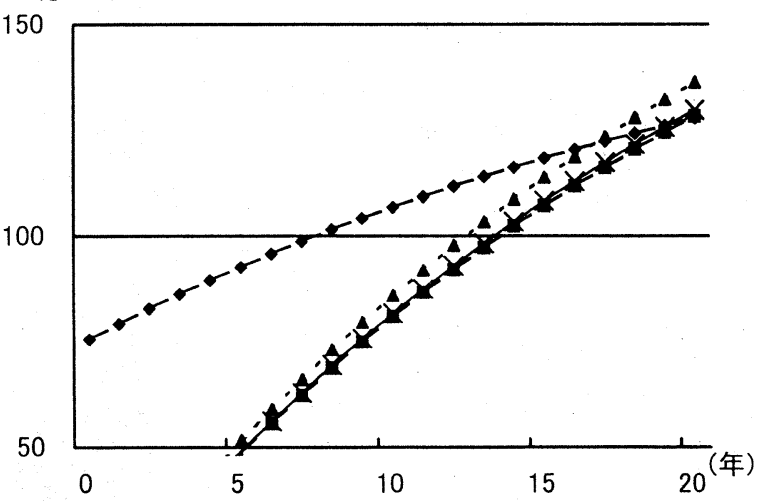

図-6 累積費用と利潤（ケース 2） 


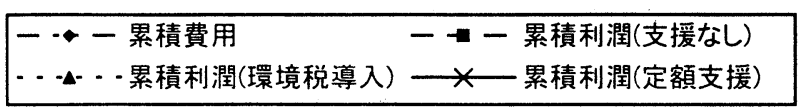

（億円）

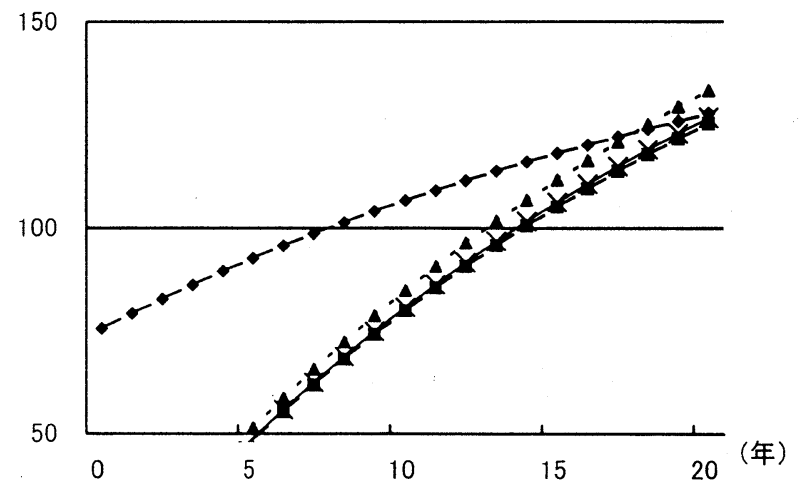

図-7 累積費用と利潤（ケース 3）

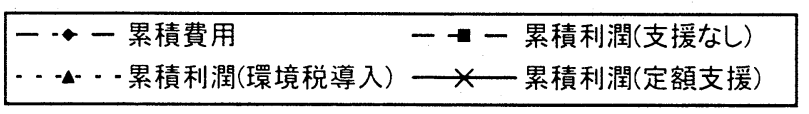

（億円）

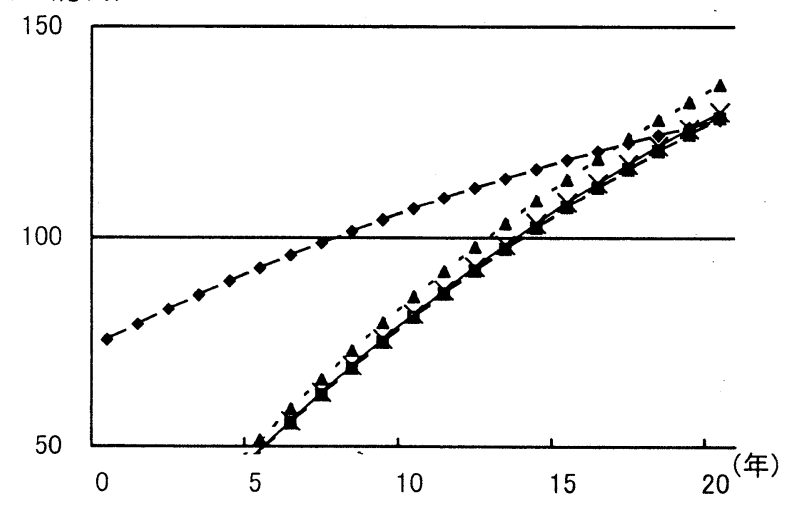

図-8 累積費用と利潤（ケース 4）
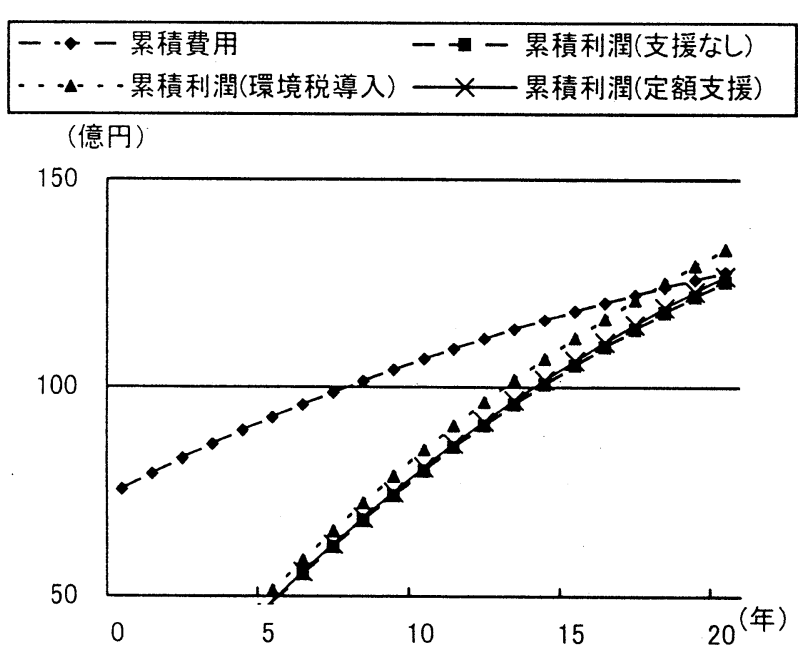

図-9 累積費用と利潤（ケース 5)

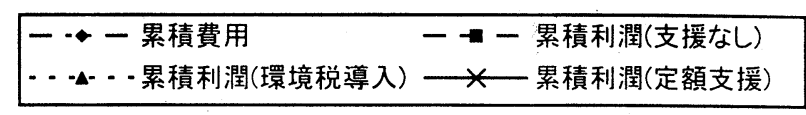

(億用)

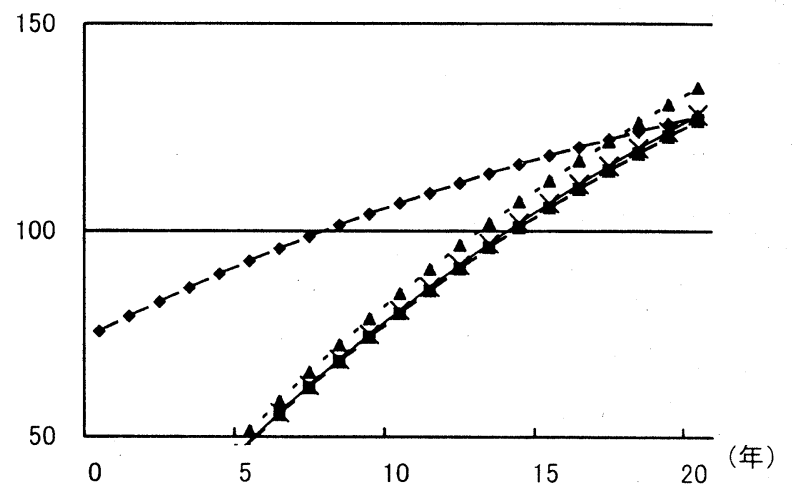

図-10 累積費用と利潤 (分担率減少)

かる経費とみなし 50 円を補助金として充当するこ ととした。また定額支援は 1 年ごとに 1 千万円補助 するということにして計測を行った。その結果ケー ス 2 やケース 4 のような緩やかな需要の減少やケー ス 3 のような 10 年間で $5 \%$ の減少では定額補助と環 境税による補助、ともに初期投資を回収することが 出来たが、ケース 5 のように速い段階で需要が低下 すると、定額補助では回収できないことがわかった。 ケース 5 の場合定額補助で事業が成立するための分 岐点の試算を併せて行ったが、その結果年間約 4 千 万円必要であるという值が算出された。

\section{（2）公共交通機関の依存度が減少する場合}

つぎに何らかの社会的要因が働き、公共交通機関 の依存度が減少した場合についての検討を行う。今 回作成した分担モデルはあくまで現況を表わすもの であり、将来の社会的な特殊要因や外的要因による 変化を捉えられない。従ってLRT 分担率が $20 \%$ 低 下した場合の費用と利潤の測定結果を図-10に示し た。このケースは環境税による補助の場合のみ初期 投資を回収することが出来た。これは環境税が他の 代替交通手段である自動車に対して課金しているた め、例え分担率が変動しても急激な減収とはならな いからであろう。

以上のすべてのケースを通じて、環境税を導入し た場合が一番早くかつ確実に初期投資を回収するこ とが出来るという結果が得られた。このことは自動 車に対して課金しその原資から補助を行う手法を用 
いることが JV 型の PFI 事業としての経営を成立さ せる最も効果的な方法であるといえる。そして同時 に採算性を向上させることにより、経営成立の確実 性が高くなり民間資金の導入を促進させることにも つながると考えられる。

\section{6. まとめ}

本研究はまずPFI 事業の成立可能性を検討するた めに必要な供給者の利潤計測手法の一つとして需給 均衡型の費用便益計測モデルを提案した。つぎに事 例研究として富山市における既存の軌道・鉄道を改 良して LRT を導入するという計画が JV 型の PFI 事 業として成立するか検討を行った。また将来交通需 要の減少や公共交通機関の依存度低下といった需要 リスクを回避するために環境税導入による補助方式 を提案し、従来の定額補助方式との比較を行った。 その結果本研究で提案した補助方式を用いることに より、需要減少に伴う供給者の採算悪化というリス クを減少させることがわかった。

この環境税は社会的損失を生み出すものに金銭 的対価を支払わせるという意味では現代社会におい て非常に利に叶っているものと思われる。しかしな がら今回対象とした都市では都市中心部に大きな川 が流れており、同時に橋の数も少ないため比較的課 金しや寸いのであろうが、このような都市形態を有 さない都市では環境税の課金方法を新たに考える必 要が出て来る。

また今後の方針としては分担率の変化によるリ
スクに対応するため、ファジイ数を導入してモデル 化を行っていきたい。

\section{【参考文献】}

1）第一勧業銀行国際金融部、PFI とプロジェクトファ イナンス、東洋経済新報社、1999

2）上田孝行,中澤毅基,福本潤也,長谷川専、民間主導型 社会資本整備事業の成立可能性に関するモデル分析、 土木計画学研究・講演集 23(2)、pp.31-34、2000

3）上田孝行,長谷川専,浅野貴志、PFI による事業方式 とリスクの分担に関する一考察、土木計画学研究 · 講演集 22(1)、pp.629-630、1999

4) 織田澤利守,横松宗太,小林潔司、公的債務保証と PFI 事業の財政的実行可能性、都市計画論文集 No.36、 pp.937-942、2001

5）小路泰広、PFI 事業における需要の不確実性を考慮 した料金設定と公的支援について、土木計画学研 究・講演集 24、2000

6）川合祐之, 青山吉隆, 中川大, 松中亮治、需要予測の 精度が異なるときの JV 型 PFI 事業の導入可能性に関 する研究、土木計画学研究・講演集 24、2000

7）梶井他、道の駅整備計画への PFI 導入可能性に関す る研究、土木学会第 55 回年講概要集、2000

8）藤田正人, 岸 邦宏, 佐藤, 馨一、PFI 方式による新交 通システムの整備計画に関する研究、第 34 回日本都 市計画学会学術研究論文集、pp.895-900、2001

\title{
A study on the reconstruction of infrastructures by PFI method considering the risks
}

\author{
By Tatsuo TAKASE, Ken KOYAMA, Kazuki MORI
}

This study estimates the technique of reconstructing the infrastructures by PFI method. The improvement of existing local transit is considered to investigate the possibility of LRT construction by the PFI method, as the case study. The various risks related to the enterprose management are taken into consideration to realize this planning. In order to decrease the demand risk that is serious to the private investor, the tax payment system for automobiles is introduced in this plan to protect the pollution by cars. 